\title{
Gente de papel e tinta: a força dos personagens ecianos
}

\author{
Flávia Aninger de Barros Rocha* \\ Alana de Oliveira Freitas El Fahl**
}

\begin{abstract}
Resumo
O presente trabalho tem por objetivo considerar que a permanência do interesse na obra de Eça de Queiroz na contemporaneidade está centrada na força da construção de suas personagens. Apresentamos, inicialmente, um breve esboço acerca da presença dos motivos ecianos na cultura através de sua citação em variadas manifestações artísticas, como a telenovela e a música popular brasileira. Em seguida apontamos que, através dos títulos das obras, o autor português já dava mostras de seu ideal de pintar as cenas portuguesas por meio de personagens complexas. Por fim, tecemos algumas considerações analíticas sobre contos ecianos a partir da perspectiva das personagens, lançando luz sobre alguns elementos que avivam a percepção da obra do autor e seu projeto literário através dessas personas singulares.
\end{abstract}

Palavras-chave: Eça de Queiroz. Personagens. Contos.

\section{People of Ink and Paper: The Strength of Eça de Queiroz' Characters}

\begin{abstract}
This work considers that the continued interest in Eça de Queiroz's work, in the present day, is centered in the strength of the characters built by the author. We present a brief study on the presence of Eça's motifs spread in the culture through quotations in several artistic manifestations such as soap operas and Brazilian popular music. Also, through the choices of titles for his novels and short stories, the Portuguese author showed his ideal of painting Portuguese scenes through complex characters. Finally, we make some analytical considerations on selected short stories from the characters' perspective built, throwing light over some elements that revive the perception of the author's work and his literary project, through these unique personas.
\end{abstract}

Keywords: Eça de Queiroz. Characters. Short stories.

Recebido: $14 / 01 / 2018$

Aceito: $20 / 05 / 2018$

\footnotetext{
* Universidade Estadual de Feira de Santana(UEFS). Departamento de Letras e Artes da UEFS. Programa de Pós Graduação em Estudos Literários - PROGEL.

** Universidade Estadual de Feira de Santana (UEFS). Professora Titular da Universidade Estadual de Feira de Santana.
} 


\section{Eça de Queiroz: um rumor que ainda se alevanta}

A circulação da ficção queirosiana está ainda longe de registrar seu ponto final. Passados mais de um século e meio de suas principais publicações, a obra de Eça de Queiroz segue abrindo caminhos para os estudos literários e outras áreas das humanidades, além de proporcionar horas de prazer aos novos leitores que ainda se entregam e se integram à sua convidativa rede de trilhas e tramas, urdida através de uma vasta galeria de personagens.

No conhecido livro de Ítalo Calvino sobre os clássicos e sua sobrevivência na cultura, Por que ler os clássicos, o autor afirma que "um clássico é um livro que nunca terminou de dizer aquilo que tinha para dizer." (CALVINO, 2000, p. 11). Tal assertiva parece contemplar a obra de alguns escritores que seguem projetando a força de suas penas muito além do seu tempo. Em consonância com esse pensamento, João Alexandre Barbosa, no ensaio “Os intervalos de Eça de Queiroz”, traz a ideia de Frank Kermode sobre a sobrevivência dos clássicos: esta deve depender da posse de um excedente de significante (surplus) (BARBOSA, 1997, p. 11). Desse modo, para o ensaísta, a continuidade de leituras, as interpretações diferenciadas e as ambiguidades permitem que se continue a estudar a obra de Eça.

Seria tarefa impossível encontrar todos os excedentes de significante presentes na obra do escritor português que ainda o tornam fonte de interesse em nossa agenda cultural. Entretanto, podemos afirmar que um dos elementos para a sua permanência e multiplicidade de interpretações possíveis está ancorado na força de suas personagens. Mais que criar narrativas instigantes para retratar no espelho estilhaçado da ficção as questões do Portugal de seu tempo, Eça construiu seres ficcionais singulares, para dar vida às cenas portuguesas e humanas. Nessa perspectiva, comentando acerca do ser vivo e do ser ficcional, Candido afirma que

a personagem deve dar a impressão de que vive, de que é como um ser vivo. Para tanto, deve lembrar um ser vivo, isto é, manter certas relações com a realidade do mundo, participando de um universo de ação e de sensibilidade que se possa equiparar ao que conhecemos na vida. (CANDIDO, 2002, p. 64-65)

Daí, talvez, por participar desse universo de sensibilidade é que se explique a nossa familiaridade quando nos parece encontrarmos com algumas criações de Eça, em nosso próprio tempo e espaço, através dos sujeitos afidalgados aos quais poderíamos chamar de "Jacinto de Tormes", ou dos discursos vazios dos nossos Conselheiros "Acácios" encontrados à mancheia em vários ambientes sociais, dos efusivos e oportunos amigos como "João da Ega" ou das peripécias sexuais e outros crimezinhos dos nossos Padres Amaros.

Destaca-se também a presença espectral de temas e personagens que são frequentemente citados, direta ou indiretamente, em obras artísticas de naturezas diversas, como na telenovela "Avenida Brasil” (2012) de João Emanuel Carneiro, exibida pela Rede Globo de Televisão, na qual o conflito entre Juliana e Luísa foi reencenado em alguns capítulos por Nina (Débora Falabella) e Carminha (Adriana Esteves), além do simbólico fato de Nina ter presenteado Tufão (Murilo Benício) com um exemplar de O primo Basílio (1878) para que ele pudesse, através da leitura da trama romanesca, enxergar o adultério de sua esposa.

O primo Basílio também se faz chegar até nós pela canção pop cantada por Marisa Monte, "Amor I love you" (2000), composta pela cantora em parceria com Carlinhos Brown, na qual um trecho do romance é enxertado ipsis litteris no corpo da letra e declamado por Arnaldo Antunes, sendo este justamente o trecho do capítulo VI que descreve as sensações de Luísa após receber uma das cartas do primo: 
(...) tinha suspirado, tinha beijado o papel devotadamente! Era a primeira vez que lhe escreviam aquelas sentimentalidades, e o seu orgulho dilatava-se ao calor amoroso que saia delas, como um corpo ressequido que se estira num banho tépido; sentia um acréscimo de estima por si mesma, e parecia-lhe que entrava enfim numa existência superiormente interessante, onde cada hora tinha o seu encanto diferente, cada passo conduzia a um êxtase, e a alma se cobria de um luxo radioso de sensações! (QUEIROZ, 1970, p. 644)

Vale notar outra recriação interessante que nutre a ideia da permanência e circulação do autor na contemporaneidade. Na minissérie O primo Basílio, adaptação do romance homônimo feita por Gilberto Braga e Leonor Basseres, exibida pela Rede Globo em 1988, em uma das primeiras cenas exibidas sobre as cavaqueiras da casa de Luísa (Giulia Gam) e Jorge (Tony Ramos), todos os personagens ali presentes olham-se individualmente no espelho da sala, gesto emblemático para validar a ideia de verossimilhança da proposta realista delineada por Eça e ali reforçada pelo diretor Daniel Filho.

Ainda poderíamos apontar a presença de outras personagens ecianas no cinema, em outras minisséries televisivas ou nas artes plásticas, revestida dos mais variados recursos intertextuais, ora mais explícitos, ora mais sutis. Essa latência nos leva novamente a Calvino, em outra premissa sobre os clássicos: "É clássico aquilo que persiste como rumor mesmo onde predomina a atualidade mais incompatível." (CALVINO, 2000, p. 15). Tais exemplos ratificam a força das criaturas ecianas, já que, insistindo em perdurar, são personagens que, mesmo na condição de rumor, habitam nosso imaginário, nossas narrativas e nosso tempo.

Ligada à ideia básica da representação, a palavra personagem, do latim persona, designava a máscara usada pelos atores de teatro que, ao colocá-la, davam corpo e voz aos seres ficcionais. Alguns etimologistas sugerem que a origem da palavra possa vir da expressão per+sonare, ou seja, a voz que soa através da máscara, remetendo-nos à voz autoral. Já a palavra character, em língua inglesa, personagem, nos sugere, em etimologia que remonta ao século XIV, um símbolo marcado ou entalhado no corpo, do grego kharax, kharassein, bastão afiado para entalhar, gravar, ou seja, o traço que define uma forma, o que nos sugere o formato delineado da personagem, como a vemos no texto literário, já como construção elaborada.

Conforme Beth Brait (2000), a discussão sobre a concepção da personagem passa pelos conceitos de Aristóteles, que apontavam para a personagem como reflexo da pessoa humana, ou seja, o artista comporia o personagem ao selecionar elementos a partir da realidade existente e lhe emprestar uma natureza única a partir dos recursos que decide utilizar. Nessa perspectiva, reiterada pelo poeta latino Horácio, por muito tempo a personagem foi associada a um modelo humano de caráter moral, como um retrato possível do melhor ser humano.

A partir de meados do século XVIII e do surgimento da forma romance, a personagem passa a ser vista como uma representação do universo psicológico do criador, em que estão presentes as paixões da alma e a crítica aos modelos políticos e sociais. Ao longo do século XIX, a personagem vai sendo tecida pelos autores com experiências humanas mais diversificadas, já que, aos poucos, em vez de fatos, privilegiam-se os eventos internos ao personagem. A visão antropomórfica da personagem permanece, no entanto, até que as discussões do século XX se dirijam para o formalismo russo, em que a obra literária passa a ser considerada como um sistema de signos organizados e a concepção de personagem se desprende da relação com o ser humano e passa a ser vista como um ser feito de linguagem.

Podemos afirmar que, dotadas de uma forma própria de existir no texto ficcional, é através das personagens e com elas que os enredos se constituem e se concretizam. Candido (2002) ilustra tal constituição, utilizando-se de uma expressão de André Gide, para quem as personagens seriam bobinas vivas nas quais o autor enrola os fios variados do enredo e a complexidade dos seus pensamentos. Deste 
modo, ainda conforme Candido, é possível dizer que a força das personagens está nos significados e valores expressos por elas, ou seja, por animar a visão de vida que decorre da narrativa.

Vale lembrar que, conforme Lukács (2000), a forma romance se estabelece a partir da influência das estruturas sociais e que as personagens ditas modernas, em confronto com o mundo, estão em um percurso de busca de sentido. Talvez seja por isso que essa gente de tinta e papel nos pareça sempre ter pertencido a contextos sociais e humanos, como os das cavaqueiras, teatros, repartições, esquinas, pensões, sacristias, praças e ruas portuguesas, do modo descrito detalhadamente por Eça.

No entanto, longe de estarem presas a uma condição restrita de tipos sociais, ou de personagens de costumes, os romances ecianos seguiram o fluxo de uma crescente complicação da psicologia das personagens, em consonância com as primeiras investigações da psicologia moderna e outros questionamentos que envolviam a concepção do homem. Brait (2000), referindo-se à literatura do século XIX, afirma que, através dessas personagens, estudavam-se particularidades humanas, pontos de interesse da psicologia e sociologia, ainda nascentes como disciplinas. Desta maneira, também de acordo com Candido (2002), o autor é capaz de direcionar o olhar do leitor para aspectos selecionados dos personagens em que estados ou processos psíquicos lembram as zonas de opacidade da pessoa real, compondo uma construção a qual não se pode sondar completamente.

A obra de Eça de Queiroz, nessa perspectiva, traz à luz perfis psicologicamente complexos, voltados para o desvendamento das aparências, tomando a personagem como um ser que não se explica apenas pelo mecanismo das relações sociais. Como exemplo, temos a intrigante Juliana Couceiro Tavira. Muito mais que uma serviçal ou uma representante de sua classe, Juliana é uma personagem que, além dos limites de parecer justa ou injusta, vítima ou algoz, não se encaixa em qualquer dicotomia à qual possamos tentar enquadrá-la. Concordando com Carlos Reis, é a personagem "mais complexa e socialmente marcante do romance”. (REIS, 2000, p. 15). Juliana serve como exemplo das várias personagens ecianas criadas como seres de exceção que, justamente por se situarem no terreno movediço das possibilidades, no jogo do mostra e esconde, por trás dos reposteiros, nos fundos dos baús, sob as cortinas das liteiras, ainda nos causam estranheza, fascínio e desejo de conhecê-los melhor. Portanto, sigamos com eles.

\section{0 barro e o sopro eciano}

Carlos Reis (2016), em "Eça de Queiroz e a personagem como ficção", ao comentar sobre a versatilidade do autor na construção de suas personagens, lembra que, além das figuras humanas, Eça buscou fazer convergir em suas narrativas, outras personagens da literatura, da mitologia e dos textos bíblicos, metaficcionalizando-as, o que confirma a importância e a complexidade do trabalho de criação das personagens por Eça. Além disso, parece-nos que os títulos dos romances de Eça de Queiroz reforçam a ideia de que o autor português, muitas vezes, criou um eixo narrativo a partir da construção da personagem, moldando o barro e soprando vida a seres de papel e tinta.

Um breve passeio pelos títulos de suas obras nos mostra que o centro das capas é ocupado por seus personagens que, ou são protagonistas ou avivarão o cerne da matéria narrativa como em $\mathbf{O}$ primo Basílio e $\mathbf{O}$ mandarim, com poucas exceções nas quais as personagens principais deslocamse para a personificação de espaços ou objetos que ocupam o protagonismo da trama num processo metonímico: O Mistério da Estrada de Cintra (1870), A tragédia da Rua das Flores (1877-78), A capital (1925/póstumo), A cidade e as serras (1901/póstumo) e A relíquia (1887). Assim temos em O crime do Padre Amaro (1875), O Primo Basílio (1878), Os Maias (1888), O mandarim (1880), A ilustre casa de Ramires (1900), A correspondência de Fradique Mendes (1900), Alves \& cia (1925/póstumo) e O conde de Abranhos (1925/póstumo), títulos que anunciam a personagem que 
será a mobilizadora principal da narrativa, ou seja, será a protagonista, aquela que primeiro luta no palco romanesco.

A relação de títulos cuja força representativa está nas personagens obedece à igual lógica nos contos de Eça. O livro Contos veio a público em 1902, em uma publicação póstuma organizada por Luiz de Magalhães, reunindo 12 narrativas publicadas anteriormente em periódicos entre os anos de 1874 e 1898: "Singularidades de uma rapariga loura" (1874), "Um poeta lírico" (1880), "No moinho" (1880), “Civilização" (1892), “A aia” (1893), “O tesouro” (1894), "Frei Genebro" (1894), “O defunto" (1894), “Adão e Eva no paraíso" (1896), “A perfeição” (1897), “José Matias” (1897) e "O suave milagre" (1898).

Usando raciocínio semelhante ao que usamos acima para dividir os romances, temos nos contos um primeiro grupo cujos títulos dizem respeito a espaços, objetos ou temas que, personificados, ganham também status de protagonismo: "No moinho", "Civilização", "O defunto", "O tesouro", "A perfeição" e "O suave milagre". No segundo grupo, os títulos referem-se aos protagonistas propriamente ditos ou ao mobilizador da ação narrativa: "Singularidades de uma rapariga loura", "Um poeta lírico", “A aia”, "Frei Genebro”, “Adão e Eva no paraíso” e "José Matias”. Teceremos algumas considerações sobre alguns contos a partir da perspectiva das personagens, lançando luz sobre alguns elementos que avivam a percepção da obra do autor e seu projeto literário através dessas personas.

\section{Três personagens e seus amores singulares}

Em “José Matias”, publicado na Revista Moderna em 1897, Eça cria uma das personagens mais complexas de sua galeria, cuja história amorosa é exposta numa intricada teia narrativa. A personagem que dá título ao conto é apresentada por um narrador, filósofo hegeliano, que relata para um amigo em comum dos tempos de Coimbra, durante o enterro de José Matias, a história do seu estranho amor por Elisa e os desdobramentos que esse sentimento trouxe para a vida do amigo falecido.

Dessa forma, a narrativa se estabelece a partir de dois momentos temporais distintos: o tempo da narração, que se dá durante o enterro de José Matias, e o tempo da matéria narrada, os longos anos do amor sem reservas de José Matias por Elisa, uma história que dura mais de vinte anos. Tal estratégia confere ao texto um ritmo dinâmico, em trânsito constante, uma espécie de troca de cenários que se interpõem durante o conto:

Linda tarde, meu amigo!... Estou esperando o enterro do José Matias, do José Matias de Albuquerque, sobrinho do Visconde de Garmilde... O meu amigo certamente o conheceu um rapaz airoso, louro como uma espiga, com um bigode crespo de paladino sobre uma boca indecisa de contemplativo, destro cavaleiro, duma elegância sóbria e fina. E espírito curioso, muito afeiçoado às idéias gerais, tão penetrante que compreendeu a minha Defesa da Filosofia Hegeliana! Esta imagem do José Matias data de 1865: porque a derradeira vez que o encontrei, numa tarde agreste de Janeiro, metido num portal da Rua de S. Bento, tiritava dentro duma quinzena cor de mel, roída nos cotovelos, e cheirava abominavelmente a aguardente (QUEIROZ, 1997, p. 1600-1601).

Para Maria Lúcia Lepecki, no verbete José Matias do “Dicionário de Eça de Queiroz”, esse conto é "superior aos outros pela estrutura complexa e pela dimensão poética da palavra" (LEPECKI, 1988, p. 539), o que confirma a atenção que o texto tem recebido da crítica eciana e, sobretudo, o interesse de seus leitores. É interessante perceber, nessa apresentação inicial do protagonista, que o narrador expõe e condensa claramente os dois "José Matias" que se conhecerá ao longo do conto: o do início, "um rapaz airoso, louro como uma espiga, com um bigode crespo de paladino sobre uma boca indecisa de 
contemplativo, destro cavaleiro, duma elegância sóbria e fina" e o do final da narrativa, o que "tiritava dentro duma quinzena cor de mel, roída nos cotovelos, e cheirava abominavelmente a aguardente".

E é justamente em torno desse intervalo entre o primeiro e o último José Matias que se constrói a matéria narrada do conto, que será desfiada pelo narrador-filósofo durante o enterro da personagem título. Há um processo de degradação, de decadência, que demanda uma explicação e que capta a atenção e a curiosidade do amigo que ouve a história de José Matias, assim como do leitor, também ele ouvinte.

Ao longo da narração, vários quadros sucessivos da história da personagem são apresentados. Aos poucos, o leitor passa a saber que sua queda física e social foi motivada pelo amor desmedido por Elisa, razão de sua vida e de sua morte. Eça caracteriza-o como um amor deslocado, um amor semelhante à coita d'amor medieval. O amor de José Matias por Elisa, inicialmente casada (depois viúva e amancebada, mas sempre pura aos seus olhos) é um tipo de amor que já não encontra compreensão nem abrigo na modernidade. Assim, antes de continuar a descrição do protagonista, o narrador coloca antecipadamente no conto, num tom que beira sutilmente a gratuidade, a outra morte de José Matias:

Vem o caixão saindo da igreja... Apenas três carruagens para o acompanhar. Mas realmente, meu caro amigo, o José Matias morreu há seis anos, no seu puro brilho. Esse, que aí levamos, meio decomposto, dentro de tábuas agaloadas de amarelo, é um resto de bêbedo, sem história e sem nome, que o frio de fevereiro matou no vão dum portal. (QUEIROZ, 1997, p. 1601).

Ao enunciar essa outra morte de José Matias, ocorrida há seis anos, Eça promove o encontro das duas matérias narrativas em jogo. Tocada pela morte do amor, a existência da personagem entra em um processo de degenerescência e morre gradativamente. Temos em seguida alguns detalhes sobre o José Matias dos tempos de Coimbra, descrito pelo narrador "como uma alma escandalosamente banal" ou "um suave camarada, sempre cordial, e mansamente risonho" e que "toda a sua inabalável quietação parecia provir duma imensa superficialidade sentimental”, perfil esse que será antecipadamente posto em xeque, quando o narrador, novamente em tom despretensioso, nos apresenta antes dessa amena fase da personagem, a sua angústia em torno do enigma que é a figura e a história de José Matias: "Pois este José Matias foi um homem desconsolador para quem, como eu, na vida, ama a evolução lógica e pretende que a espiga nasça coerentemente do grão". (QUEIROZ, 1997, p. 1602).

É necessário não perder de vista o fato de o narrador ser um filósofo hegeliano. Logo, é com base nesse discurso que o narrador-filósofo tenta compreender, através da lógica que compõe o seu repertório intelectual, um homem que contraria esse mesmo espírito lógico, por amar além da conta. Todavia, o desejo do narrador de encontrar uma resposta não se concretiza. José Matias permanecerá inexplicável. Preso ao seu cabedal científico, o narrador não consegue traduzir o amor singular do rapaz louro. Assim, com a ironia que lhe é peculiar, Eça esvazia de sentido o discurso hegeliano, mostrando-o como instrumento limitado diante da complexa condição humana.

Outra personagem singular é Luiza, que mobilizará a ação narrativa que dá vida ao primeiro conto publicado pelo autor. "Singularidades de uma rapariga loura" foi inicialmente publicado em 1874, no "Brinde aos senhores assinantes" do Diário de Notícias. O conto é narrado em terceira pessoa por um viajante, hóspede de uma pensão, que terá como companheiro de quarto Macário. Este, de fato, nos põe em contato com a rapariga loura, centro da ação narrativa e do amor-ruína de Macário.

Um ponto estilístico em destaque no conto é o grande teor descritivo que Eça imprime ao texto. Todos os ambientes e as personagens principais, secundárias e até mesmo os meros figurantes são descritos com riqueza de detalhes, como na passagem em que descreve pares de sapatos à porta dos quartos da hospedaria. Vejamos um pequeno exemplo, no qual as pequenezas são inventariadas, mesmo sem uma importância maior para o enredo central: 
A minha curiosidade começou à ceia, quando eu desfazia o peito de uma galinha afogado em arroz branco, com fatias escarlates de paio - e a criada, uma gorda e cheia de sardas, fazia espumar o vinho verde no copo, fazendo-o cair de alto de uma caneca vidrada: o homem estava de fronte de mim, comendo tranquilamente a sua geleia: perguntei-lhe, com a boca cheia, o meu guardanapo de linho de Guimarães suspenso nos dedos - se ele era de Vila Real. (QUEIROZ, 2004, p. 168-169).

A marca realista de espelhamento do real, de anatomia do caráter, se impõe no texto para estabelecer na personagem central uma patologia singular, a cleptomania. Nessa perspectiva, Eça coloca em cena o tecido social doentio, marcado por assimetrias sociológicas e psicológicas. A doença vai se anunciando no conto lentamente, através de uma sucessão de indícios. Assim, Macário, um jovem correto, justo e trabalhador cairá de amores por Luiza, tão bela quanto vazia e depois, ao descobrir que esta é uma ladra, terá sua idealização destruída. Tudo é singular no conto, mas não tão simples, de acordo com a concepção de Maria Helena Nery Garcez:

Opõem-se, portanto, singularidade e simplicidade, entendido este último termo na acepção de limitado, curto, terra a terra. O leitor passa, então, a ver Macário menos como vítima de um drama de amor que como vítima da própria intolerância e limitação. Mais do que amar uma pessoa, Macário amava a honestidade palpável, a honra palpável, a retidão palpável e, de tal forma que, mesmo passados tantos anos do caso, nem o entendia nem o avaliava de outra forma. O retrato que Eça de Queiroz faz da rigidez obtusa de Macário e de seu caso simples é radical. Singularidades, ao criar o encontro de um espírito rasteiramente positivo com a psique patológica de uma cleptomaníaca, é, indubitavelmente, paradigmático do realismo/naturalismo. (GARCEZ, 2000, p. 240).

É interessante notar que as descrições de Luiza ao longo do conto, feitas por Macário, vão se alterando com o passar do tempo. Mesmo antes que Macário saiba, o leitor percebe que a dúvida sobre o caráter de Luiza está instaurada pela oposição entre sua beleza física e os traços psicológicos delineados pelo narrador:

Era uma rapariga de vinte anos, talvez - fina, fresca, loura como uma vinheta inglesa: a brancura da pele tinha alguma coisa de transparência das velhas porcelanas, e havia no seu perfil uma linha pura., como de uma medalha antiga e os velhos poetas pitorescos ter-lheiam chamado - pomba, arminho, neve e oiro. (QUEIROZ, 2004, p. 172).

Segundo me disse Macário - era muito singular o temperamento de Luísa. Tinha o carácter louro como o cabelo - se é certo que o louro é uma cor fraca e desbotada: falava pouco, sorria sempre com os seus brancos dentinhos, dizia a tudo «pois sim»; era mais simples, quase indiferente, cheia de transigências. Amava decerto Macário, mas com todo o amor que podia dar a sua natureza débil, aguada, nula. Era como uma estriga de linho, fiava-se como se queria: e às vezes, naqueles encontros nocturnos, tinha sono. (QUEIROZ, 2004, p. 184).

Podemos observar como o narrador desloca a rapariga loura, antes digna de louvores, para o terreno da suspeita, ao enumerar adjetivos que não mais a idealizam, fazendo-a descer ao chão da desconfiança. Antes, seus traços físicos, como o louro dos seus cabelos e seu talhe, eram associados a símbolos positivos como porcelana e ouro das velhas medalhas. Agora o fulgor sugere esmaecimento, debilidade, fraqueza. A descrição trabalha a serviço do desenrolar da trama e da surpresa da descoberta de sua falha moral.

A protagonista do conto "No moinho", publicado em "O Atlântico" em 28 de abril de 1880, é Maria da Piedade, uma jovem e bonita senhora, casada com um velho enfermo e mãe de três crianças igualmente enfermas, que dedica todo o seu tempo aos cuidados da família. Além disso, também administra os bens do esposo, impossibilitado de exercer as funções masculinas por conta da invalidez, 
incluindo-se aí a sexualidade.

Ao receber a visita inesperada do primo de seu marido, o afamado escritor Adrião, sua vida muda irremediavelmente. O visitante desperta em Piedade inquietação e desejo, sensações até então desconhecidas ou reprimidas. Após um beijo trocado no idílico moinho que dá nome ao conto e da brusca partida do primo, Maria da Piedade transforma-se num ser em ebulição, abandona sua devota vida doméstica e passa a viver em função da satisfação de suas fantasias.

Inicialmente, a ausência de uma vida sexual parece ser sublimada pela rotina de enfermeira e administradora da casa e das propriedades; com o decorrer do enredo, essa sublimação será posta em xeque. A admiração da vila sustenta o comportamento piedoso e aplaude o sacrifício constante da personagem, na introdução do conto:

D. Maria da Piedade era considerada em toda a vila como "uma senhora modelo". O velho Nunes, diretor do correio, sempre que se falava nela, dizia, acariciando com autoridade os quatro pêlos da calva: - É uma santa! É o que ela é! A vila tinha quase orgulho na sua beleza delicada e tocante; era uma loura, de perfil fino, a pele ebúrnea, e os olhos escuros de um tom de violeta, a que as pestanas longas escureciam mais o brilho sombrio e doce. Morava ao fim da estrada, numa casa azul de três sacadas; e era, para a gente que às tardes ia fazer o giro até ao moinho, um encanto sempre novo vê-la por trás da vidraça, entre as cortinas de cassa, curvada sobre a sua costura, vestida de preto, recolhida e séria. Poucas vezes saía. O marido, mais velho que ela, era um inválido, sempre de cama, inutilizado por uma doença de espinha; havia anos que não descia à rua; avistavam-no às vezes também à janela murcho e trôpego, agarrado à bengala, encolhido na robe-de-chambre, com uma face macilenta, a barba desleixada e com um barretinho de seda enterrado melancolicamente até ao cachaço. (QUEIROZ, 1997, p. 1498).

É possível logo perceber a assimetria entre a beleza e juventude da esposa e o estado débil do marido e dos filhos. Maria Piedade, loura e delicada, é a única nota de vivacidade no ambiente lúgubre e doentio da casa. $\mathrm{O}$ nome da personagem nos remete imediatamente à religiosidade cristã. Nossa Senhora da Piedade representa a mãe que recebe Jesus Cristo em seus braços depois da crucificação e leva seu corpo, com os discípulos, para o sepulcro. É uma das imagens mais conhecidas na arte sacra, representada por Nossa Senhora com Jesus morto em seu colo, a exemplo da Pietá de Michelangelo. O seu sofrimento sugere resignação como caminho para a perfeição, tendo o sofrimento de Cristo, assim como o da Santa Mãe, como exemplos. Nossa Senhora da Piedade também é conhecida como Nossa Senhora das Dores, ou a Mater Dolorosa.

Além disso, juntamente com sabedoria, conselho, fortaleza e temor de Deus, a piedade é considerada como um dos dons espirituais, ou virtudes que sustentam a vida moral do ser humano, consideradas como disposições permanentes que tornam o homem dócil aos impulsos do Espírito Santo. Logo, o nome escolhido por Eça é motivado pela relação intrínseca com a ideia de santidade e virtude supostamente vivenciadas pela personagem. Desenvolvido na perspectiva da ironia, o conto desfaz a sacralidade da Mater Dolorosa, na medida que põe a nu o ser corruptível, dominado pelo desejo e pela ânsia de prazer.

Após o beijo, divisor de águas que dará novos rumos para a vida de Piedade, o conto acelera seu ritmo, como se o moinho, antes desativado, passasse a impulsionar rapidamente a narrativa e também o movimento da roda da fortuna. Na sequência, Adrião, após rápida visita à casa de Piedade, onde a encontra em cuidados com o filho doente, reflete sobre o absurdo dos seus planos de viver com aquela mulher e acha-se odioso por pensar em tirá-la de sua família. Volta no dia seguinte apenas para se despedir friamente, mal sabendo da reviravolta que seu gesto causaria.

Adrião parte, deixando marcas indeléveis. Piedade tomara consciência da sua miséria. Os cuidados antes dispensados com dedicação transformam-se em um fardo pesado demais. Para aliviá-lo, procura os caminhos da imaginação. Assim, através da ficção, como Madame Bovary, Piedade passa a encher de fantasia a sua existência vazia: 
Refugiava-se então naquele amor como uma compensação deliciosa. Julgando-o todo puro, todo de alma, deixava-se penetrar dele e da sua lenta influência. Adrião tornara-se, na sua imaginação, como um ser de proporções extraordinárias, tudo o que é forte, e que é belo, e que dá razão à vida. Não quis que nada do que era dele ou vinha dele the fosse alheio. Leu todos os seus livros, sobretudo aquela Madalena que também amara, e morrera dum abandono. Essas leituras acalmavam-na, davam-lhe como uma vaga satisfação ao desejo. Chorando as dores das heroínas de romance, parecia sentir alívio às suas. [...] Lentamente, essa necessidade de encher a imaginação desses lances de amor, de dramas infelizes, apoderou-se dela. Foi durante meses um devorar constante de romances. Ia-se assim criando no seu espírito um mundo artificial e idealizado. A realidade tornava-se-lhe odiosa, sobretudo sob aquele aspecto da sua casa, onde encontrava sempre agarrado às saias um ser enfermo. (QUEIROZ, 1997, p. 1505).

A experiência vivida com o primo e a busca do romance nas páginas dos livros estabelece uma espécie de educação sentimental, educação que, ironicamente, ao invés de fazê-la ascender, a levará à queda. O tema da educação romântica como elemento negativo na formação de Portugal é uma constante na obra do autor, como se evidencia em "Os Maias" ou em "O primo Basílio". No presente conto, o tema também surge como alvo das críticas de Eça.

Piedade lê os livros escritos por Adrião, entre eles, "Madalena", história que entra em conexão com a sua: uma mulher que amara e morrera de um abandono. Percebe-se aqui procedimento semelhante à presença do drama "Honra e paixão", escrita por Ernestinho Ledesma, personagem escritor de "O primo Basílio". Eça introduz a ficção dentro da ficção, como uma espécie de confirmação do destino das suas protagonistas.

Como criador de histórias, Adrião foi também capaz de fabricar em Piedade, uma outra Madalena, vítima de abandono. Se a personagem ficcional morre, de fato, Piedade morrerá simbolicamente, já que dará lugar a uma outra mulher nada piedosa. O livro, além de resumir o enredo da vida de Piedade, ao cruzar tragicamente seu destino com o primo sedutor, de imediato nos remete à personagem bíblica, narrada no Evangelho de João 8: 1-11.

Adúltera levada pelos escribas e fariseus à presença de Jesus no templo, Madalena é perdoada pelo Messias. Pela lei de Moisés, as adúlteras deveriam ser apedrejadas, por isso Jesus lança para os homens presentes, o julgamento. Madalena é absolvida pelos seus juízes, pois ninguém se julgou capaz de condená-la. O Mestre, então, ao liberá-la, ordena que não peque mais. Ao trazer a referência bíblica, Eça dialoga criticamente com as Escrituras. Se, no Evangelho, o perdão para Madalena foi concedido mediante a sua posterior correção de comportamento, Piedade, essa outra Madalena, não poderá ser absolvida moralmente aos olhos do povo da vila campesina.

Outro elemento apontado no texto como modificador do comportamento de Piedade é a prática da leitura. A leitura tem especial relevo para muitas personagens ecianas, funcionando também como uma espécie de personagem que convive com as demais e influencia seus destinos. Temos em Piedade um exemplo interessante do modo como Eça inscreve o papel da ficção em suas obras.

Neste caso, a leitura representará um choque para Piedade, mulher oprimida numa sociedade atrasada. Na sequência, a leitura romântica a leva à perdição, mas de algum modo a liberta, porque a faz transgredir o quadro de sua opressão. Diferentemente de Luiza, que já era uma voraz leitora de romances quando se envolve com Basílio, Piedade só entra no universo ficcional através do contato com Adrião. A primeira vai do bovarismo ao donjuanismo. A segunda faz o percurso inverso: o donjuanismo a leva ao bovarismo. Sobre a presença do livro na obra de Eça, afirma Maria do Rosário da Cunha Duarte (1997) no artigo “A inscrição da leitura na ficção queirosiana”:

Mas a presença do livro e da leitura no romance queirosiano ultrapassa a ficcionalização da realidade cultural em que se movia a média burguesia urbana. Inscrita na ficção, a leitura passa a funcionar como um signo gerador de sentidos, enquanto o livro, como objeto, 
participa na construção do espaço, revelando-se frequentemente um elemento indissociável da atitude física da personagem. (DUARTE, 1997, p. 350).

Dessa maneira, a leitura passa a funcionar como um desestabilizador da rotina doméstica. Através da ficção, Piedade passa a ver o lado sombrio de seu mundo e passa a achar suas obrigações cotidianas cada vez mais detestáveis. Anunciado pelo beijo, o adultério completa-se pela via da leitura. Nesse sentido, há uma gradação que vai do beijo ao romance, do romance à poesia e desta última ao texto dramático. Se primeiro eram as personagens dos romances que povoavam as fantasias de Piedade, prometendo outras vidas possíveis, a poesia a faz mergulhar mais profundamente em si mesma, num exercício de introspecção caro à modernidade.

Chegando por fim aos textos do teatro, ela sonha e deseja o encontro noturno entre Romeu e Julieta. Ao inventar para si um amante que salta balcões e que vem visitá-la em sua prisão doméstica, Piedade emancipa-se de Adrião, ao modo de uma persona dramática que se emancipa do autor. Nessa terceira etapa, Piedade passa a desejar qualquer corpo que possa saciar seus anseios. Do amante ideal, ela cede ao amante real, ou antes, ao amante possível, como o final do conto evidencia.

O seu amor desprendeu-se pouco a pouco da imagem de Adrião e alargou-se, estendeu-se a um ser vago que era feito de tudo o que a encantara nos heróis de novela; era um ente meio príncipe e meio facínora, que tinha, sobretudo, a força. Porque era isto que admirava, que queria, por que ansiava nas noites cálidas em que não podia dormir - dois braços fortes como aço, que a apertassem num abraço mortal, dois lábios de fogo que, num beijo, lhe chupassem a alma. Estava uma histérica. [...] E o romanticismo mórbido tinha penetrado naquele ser, e desmoralizara-o tão profundamente, que chegou ao momento em que bastaria que um homem lhe tocasse, para ela lhe cair nos braços: - e foi o que sucedeu enfim, com o primeiro que a namorou, daí a dois anos. Era o praticante da botica. (QUEIROZ, 1997, p. 1506).

Ao se desapegar da imagem de Adrião, que seria a representação do amor ideal, Piedade aceita uma ínfima satisfação que em nada lembra a imagem do amante em suas leituras. Em percurso que nos remete à Elisa de José Matias, ela também se contentará com uma parca relação sexual com o praticante de botica, figura ambígua, que simultaneamente desperta repulsa e atração pela sua potência. $\mathrm{O}$ aprendiz de boticário constitui remédio para a carência, substituindo precariamente a ausência do amante perfeito, que aliaria o poder exercido pela literatura à potência física. A personagem, tal qual a rapariga loura de Macário, desfigura-se, ou melhor, transfigura-se. O campo das virtudes se esvazia para dar lugar aos vícios.

Em José Matias, Eça constrói uma personagem capaz de viver um amor que a um só tempo é patológico e fascinante; através de Piedade, coloca em evidência a complexidade do conflito humano entre o dever moral e o desejo de amar. Com Luiza, não a de Basílio, mas a amada do íntegro e valoroso Macário, temos a quebra do padrão da musa romântica, através da criação de uma protagonista cuja imagem externa contraria sua imagem moral.

Foi possível verificar como o enredo das narrativas aqui analisadas depende intrinsecamente da construção de cada personagem, realizada com riqueza de detalhes e fina ironia eciana. Notamos também como a pena do autor ultrapassa seu tempo e nos alcança com o frescor de uma primeira leitura. Suas personagens, essa gente de sangue e tinta, continuam em nossos estudos, linhas sempre inconclusas e em busca de novos excedentes de significados. Os contos aqui analisados mostram a grandeza de um autor que, criando seres feitos de linguagem, parece alcançar a alma humana. 


\section{Referências}

BARBOSA, João Alexandre. Os intervalos de Eça de Queiroz. In: QUEIROZ, Eça. Obras completas: vol. II. Rio de Janeiro: Ed. Nova Aguilar, 1997.

BRAIT, Beth. A personagem. $7^{\text {a }}$ edição. São Paulo: Ed. Ática, 2000.

CALVINO, Italo. Por que ler os clássicos. São Paulo: Cia. das Letras, 2000.

CANDIDO, Antonio et al. A personagem de ficção. 10 edição. São Paulo: Ed. Perspectiva, 2002.

DUARTE, Maria do Rosário da Cunha. "A inscrição da leitura na ficção queirosiana”. In: MINÉ, Elza e CANIATO, Benilde Justo (Org). 150 Anos com Eça de Queiroz. Anais do III Encontro Internacional de Queirosianos. USP: São Paulo, 1997.

GARCEZ, Maria Helena Nery. “O amor e seus casos simples...” Revista Via Atlântica. São Paulo, n. 4., p. 238-248, dez. 2000.

LEPECKI, Maria Lúcia. José Matias. In: MATOS, A. Campos de (Org.). Dicionário de Eça de Queiroz. Lisboa: Ed. Caminho, 1988.

LUKÁCS, Georg. A teoria do romance: um ensaio histórico-filosófico sobre as formas da grande épica. Tradução, posfácio e notas de José Marcos Mariani de Macedo. São Paulo: Duas Cidades, 2000.

QUEIROZ, Eça de. Contos I: Edição crítica das obras de Eça de Queiroz. Lisboa. Imprensa Nacional - Casa da Moeda, 2004.

QUEIROZ, Eça. Obras Completas: vol. I. Rio de Janeiro: Ed. Aguilar, 1970.

QUEIROZ, Eça. Obras completas: vol. II. Rio de Janeiro: Ed. Nova Aguilar, 1997.

REIS, Carlos. O essencial sobre Eça de Queirós. Lisboa: Ed. Imprensa Nacional, 2000.

REIS, Carlos. Eça de Queirós e a personagem como ficção. Revista de Estudos Literários. Coimbra, n.6, p.29-60, 2016. 
